\title{
Clinical and genetic factors associated with suicide in mood disorder patients
}

\author{
Niki Antypa ${ }^{2} \cdot$ Daniel Souery $^{3} \cdot$ Mario Tomasini $^{1} \cdot$ Diego Albani $^{4} \cdot$ Federica Fusco $^{4}$. \\ Julien Mendlewicz ${ }^{3} \cdot$ Alessandro Serretti $^{1}$
}

Received: 22 April 2015 / Accepted: 17 November 2015 / Published online: 1 December 2015

(C) Springer-Verlag Berlin Heidelberg 2015

\begin{abstract}
Suicidality is a continuum ranging from ideation to attempted and completed suicide, with a complex etiology involving both genetic heritability and environmental factors. The majority of suicide events occur in the context of psychiatric conditions, preeminently major depression and bipolar disorder. The present study investigates clinical factors associated with suicide in a sample of 553 mood disorder patients, recruited within the 'Psy Pluriel' center, Centre Européen de Psychologie Médicale, and the Department of Psychiatry of Erasme Hospital (Brussels). Furthermore, genetic association analyses examining polymorphisms within COMT, BDNF, MAPK1 and CREB1 genes were performed in a subsample of 259 bipolar patients. The presence or absence of a previous suicide attempt and of current suicide risk were assessed. A positive association with suicide attempt was reported for younger patients, females, lower educated, smokers, those with higher scores on depressive symptoms and higher functional disability and those with anxiety comorbidity and familial history of suicidality in first- and seconddegree relatives. Anxiety disorder comorbidity was the
\end{abstract}

Alessandro Serretti

alessandro.serretti@unibo.it

1 Department of Biomedical and NeuroMotor Sciences, Institute of Psychiatry, University of Bologna, Viale Carlo Pepoli 5, 40123 Bologna, Italy

2 Department of Clinical Psychology, Institute of Psychology, Leiden University, Leiden, The Netherlands

3 Laboratoire de Psychologie Medicale, Centre Europe'en de Psychologie Medicale, Universite' Libre de Bruxelles and Psy Pluriel, Brussels, Belgium

4 Laboratory of Biology of Neurodegenerative DisordersNeuroscience Department, IRCCS Istituto di Ricerche Farmacologiche "Mario Negri", Milan, Italy stronger predictor of current suicide risk. No associations were found with polymorphisms within COMT and BDNF genes, whereas significant associations were found with variations in rs13515 (MAPK1) and rs6740584 (CREB1) polymorphisms. From a clinical perspective, our study proposes several clinical characteristics, such as increased depressive symptomatology, anxiety comorbidity, functional disability and family history of suicidality, as correlates associated with suicide. Genetic risk variants in MAPK1 and CREB1 genes might be involved in a dysregulation of inflammatory and neuroplasticity pathways and are worthy of future investigation.

Keywords Depression - Bipolar - Mood disorder . Suicide $\cdot$ Single nucleotide polymorphism $\cdot$ Genetic association study

\section{Introduction}

Mood disorders include major depressive (MDD) and bipolar (BD) disorders [1], common psychiatric conditions within the general population [2]. It has been estimated that up to $15 \%$ of the population will experience at least one mood disorder episode during their lifetime [3], leading to moderate-to-severe impairment in working and social activities and accounting for a significant burden in terms of days lost. Although the majority of psychiatric diseases present an increased liability toward suicidal behavior [4], patients affected by mood disorders are exposed to the highest risk [5]: The mortality rates due to completed suicide are up to $15 \%$ in MDD [6, 7] and $10 \%$ in BD [4]. A strong relationship connects mood disorder episodes, in particular depressive states, with suicidal ideation and attempt [8]. Therefore, the assessment of suicidal risk and 
the prevention of suicide attempt in patients suffering from mood disorders is crucial, even if an accurate evaluation often remains a challenge for psychiatrists.

Both retrospective and prospective studies have investigated suicidality in mood disorder patients, identifying several predisposing factors. The main demographic feature involved in increasing risk of suicide attempts is the female gender, whereas males are more likely to have a completed suicide [9-11]. Clinical factors that increase the risk of suicide attempt include: early onset of disease [12], high severity of depressive episodes [13], longer period of undiagnosed and untreated illness [14] and discontinuation of antidepressants [15]. A considerable number of studies relate suicide attempts and completions to feelings of hopelessness and higher scores on subjective depression levels [16-21]. Higher levels of suicidal tendencies have been suggested as the best predictor of completed suicide [18]. An increased likelihood of a suicide attempt has been described in persons who have experienced adverse life events [22] and use tobacco [8]. Among bipolar patients, additional risk factors for suicide attempts are the presence of rapid-cycling and mixed states [23] and depressive episodes at onset [24]; on the contrary, preponderance of manic episodes appears to be a risk-reducing factor [25]. A previous history of suicide attempt is the most reliable single predictor of future suicidal behavior (both attempted and completed suicide) in patients affected by mood disorders [20, 26-28]. Several comorbidities lead to an increased susceptibility toward suicidal conduct: anxiety disorders [23], eating disorders [29], alcohol and substance abuse $[25,30,31]$, personality disorders [32] and anger-related/ impulsive temperamental tracts [33]. Finally, in patients with positive anamnesis for a suicide attempt, a family history of mental illness [20] and suicidal behavior [28] is frequently found.

The heritability of completed suicide is about $40 \%$ [34], with minor contribution of shared family environmental factors; nevertheless, the precise genetic predisposition has not been fully understood yet. Strong neurobiological evidence points toward serotonergic and noradrenergic dysfunction [35-37]. Dysregulation in serotonin (5-HT) neurotransmission also appears to be related to impulsiveaggressive behavior [38], which influences suicidal behavior as an intermediate phenotype [39]. Genetic studies have identified several candidate genes involved in the dopaminergic and other neurotransmitter pathways [40].

The catechol-O-methyltransferase (COMT) gene, located on chromosome 22, synthesizes an enzyme responsible for the degradation of catecholamines. The most studied variant (rs4680) involves a valine-methionine substitution at codon 158 (Val158Met), resulting in a high or low functional activity of the enzyme [41]. In particular, Val/Val genotypes present $40 \%$ higher enzymatic activity compared with Met/Met genotypes [42]. COMT effects can be modulated by exposure to stress, particularly in the pathophysiology of depressed mood and related neurocognitive processes [43]. A meta-analysis conducted by Kia-Keating [44] found significant association between this variant and suicidal behavior. Nevertheless, more recent studies [45-48] reported no relationship between Val158Met and suicide. Other researchers [49-52] explored the link between Val158Met and personality traits, such as novelty seeking/extraversion trait and violent behavior, with mixed results. While mostly rs 4680 has been extensively investigated so far, other less examined variants within COMT gene could also alter the enzymatic efficiency in catabolizing catecholamines [53, 54].

Another commonly studied gene is the brain-derived neurotrophic factor (BDNF) gene, located on chromosome 11 , and expressed in a high number of cerebral structures; it codes for a homodimeric protein which plays an important role in neuronal development and synaptic plasticity. BDNF has also been previously implicated in suicidal behavior [55]. A postmortem study detected reduced mRNA levels of BDNF in the prefrontal cortex and hippocampus of suicide subjects [56] and a meta-analysis reported significantly lower serum BDNF levels in depressed patients, compared with healthy controls [57]; furthermore, successful antidepressant treatment leads to an increment in BDNF secretion [58]. The valine-66-methionine polymorphism (rs6265), resulting in a modulation of BDNF activity-dependent secretion [59], has been observed to be associated with BD [60, 61], especially in patients with rapid cycling [62, 63]. Nevertheless, three studies and a meta-analysis [64-67] demonstrated a significant association between Met allelecarrying genotypes and a higher risk of suicide attempts in depressed patients. Another meta-analysis reported better response to selective serotonin reuptake inhibitors (SSRI) treatment in depressed patients with heterozygous genotypes for Val66Met, compared with homozygous genotypes [68]. A less studied polymorphism (rs11030101) within the BDNF gene has been previously associated with BD [69].

Two other, not well investigated, genes that could be implicated in the genetic susceptibility to suicide are the mitogen-activated protein kinase 1 (MAPK1) gene and the cyclic adenosine monophosphate response element-binding protein-1 (CREB1) gene. The MAPK1 gene, located on chromosome 22, encodes a member of the MAP kinase family. Of various MAPKs, extracellular signal-regulated kinase 1/2 (ERK1/2) is involved in neuronal proliferation and differentiation and synaptic plasticity [70, 71]. In addition, through the activation of nitric oxide and pro-inflammatory cytokines, it plays an important function in inflammatory processes [72]. Dysregulation in MAPK1 signaling pathway is involved in MDD and suicidal behavior [73]; an alteration of MAPK1 levels has been documented in the 
frontal cortex of patients with schizophrenia, BD and MDD [74]. In rodents, decreased phosphorylation of ERK1/2 induced depressive-like behavior [75], while treatment with fluoxetine increased the activity of ERK1/2 signaling and led to an alleviation of depressive symptoms [76]. Other studies showed an involvement of MAPK1 in relation to antidepressants [77], mood stabilizers [78] and antipsychotics [79]. These findings suggest a possible role of MAPK1 pathway in response to depression and exposure to stress; in support of this hypothesis, BDNF may improve depressive symptoms through the stimulation of ERK1/2 signaling [80].

The CREB1 gene is situated on chromosome 2; it encodes a transcription factor member of the leucine zipper family of DNA-binding proteins, which is a downstream target of MAPK1 pathway [81]. There is a close association between MAPK1 and CREB1 as they are both involved in the regulation of neuronal plasticity and inflammatory pathways [82], which retain a fundamental role in the pathophysiology of MDD [75]. Furthermore, an association between CREB1 and response to antidepressants [83] and mood stabilizers [84] has been found. Most importantly, two studies have shown that in postmortem brains of suicide subjects there are a decreased mRNA expression and functional parameters of CREB [85, 86], thereby signaling that CREB-related genes may play an important role in suicide.

The aim of the present study was twofold. Firstly, we examined clinical factors associated with a history of suicide attempt in a sample of 553 mood disorder patients; the selection of variables subject to study was based on factors arising from the literature. Secondly, we investigated in a subsample of 259 bipolar patients the association between several polymorphisms within COMT, BDNF, MAPK1 and CREB1 genes and suicide attempt status; the selection of these candidate genes is based on previous data suggesting their involvement in pathophysiologic mechanisms underlying suicidal behavior. Two single nucleotide polymorphisms (SNPs) (rs4680 and rs174696) within the COMT gene were examined: The former one is located in the coding exon, while the latter one belongs to the intron. We also examined four SNPs (rs6265, rs11030101, rs11030104 and rs12273363) within the BDNF gene: The first is a functional polymorphism, while the second belongs to the $5^{\prime}$ untranslated region (5'-UTR); the other two SNPs are situated in the promoter region. Within the MAPK1 gene, we tested four SNPs (rs6928, rs13515, rs3810608 and rs8136867) for their association with suicide attempt status: The first two SNPs are placed in the $5^{\prime}$-UTR, while the latter two belong to the intronic sequence. We also examined four SNPs (rs889895, rs2254137, rs6740584 and rs2551922) within the CREB1 gene, all found in the intronic region.

\section{Methods}

\section{Participants}

The participants of the present study have been recruited between March 2004 and March 2009 within the 'Psy Pluriel' center, Centre Européen de Psychologie Médicale, and the Department of Psychiatry of Erasme Hospital (in- and outpatients) in Brussels. The assessment of mood disorder patients was completed using the software program 'COPEBipolar.COM' (Clinical Outcome Measures for Bipolar Disorder), consisting of structured examination tools and immediate data capture. It is composed of 10 modules: each of them is dedicated to essential elements of unipolar and bipolar disorders, such as sociodemographic characteristics, psychiatric antecedents, diagnosis and treatment, quality of life and functioning. Patients were included if they met DSM-IV criteria for a diagnosis of mood disorder (BD and/or MDD). Approximately $40 \%$ of the patients had an illness onset during the previous 6 months before admission and were seeking treatment for the first time, whereas another $27 \%$ of the sample had an illness onset of more than 5 years. Mental retardation, dementia, neurologic disorder and severe organic disease were exclusion criteria. Written informed consent was obtained from all participants in the study after local ethical committee approval was obtained. For a detailed description of the sample, see [87].

\section{Assessments}

Clinical interviews were conducted by specifically trained psychiatrists. Lifetime diagnosis, course of illness and comorbidities of patients were assessed on the basis of the Mini-International Neuropsychiatric Interview (MINI) [88]. Severity of mood symptoms of the most recent episode was assessed using the Hamilton Rating Scale for Depression (HDRS) [89], the Montgomery and Asberg Depression Rating Scale (MADRS) [90] and the Young Mania Rating Scale (YMRS) [91]. Severity of functional impairment subsequent to the psychiatric disease was assessed using the Sheehan Disability Scale (SDS) (Sheehan 1983). The presence or absence of a previous suicide attempt was established according to the MINI. Current suicidal risk was also assessed with the MINI interview and coded as present or absent. Psychiatric familial antecedents were screened for each patient: familial history of MDD and BD in first-degree relatives and familial history of suicide attempt in first- and second-degree relatives.

Genotyping Genomic DNA (gDNA) was purified from whole peripheral blood samples with an automated workstation (Maxwell, Promega) and checked for quality $(260 / 280$ ratio $>1.6)$ and quantity $(>15 \mathrm{ng} / \mathrm{L})$ by a 
small-scale spectrophotometer (Nanodrop, Thermo Scientific). The genotyping was performed using $20 \mathrm{ng}$ of gDNA on a Sequenom MassARRAY platform (Sequenom, California, USA) together with the iPLEX assay (http://www. sequenom.com). Genotyping was then performed according to the manufacturer's standard protocols. MassARRAY Typer version 4.0 3.4 was used to read the extended mass and genotype calls. SNPs were selected following a series of criteria: relevant previous findings, MAF $>5 \%$, validated and tagging. For some SNPs, genotyping was performed by restriction fragment length polymorphism (RFLP), based on PCR followed by restriction enzyme analysis. Forward and reverse primers' sequences are available upon request. Genotyping success rate was above $95 \%$. Genotype data were available for 259 patients.

\section{Statistical analysis}

Statistical analysis was performed using Statistical Package for Social Science (SPSS, IBM 20.0); Chi-square $\left(\chi^{2}\right)$ tests and Student's $t$ tests were used to compare groups with history or no history of suicide attempt(s) on a range of categorical and continuous variables. Logistic regressions were run to examine which factors were associated with current suicidal risk.

\section{Results}

\section{Sociodemographic characteristics}

The presence or absence of a suicide attempt was the main outcome of interest. Within our sample $(n=553), 221$ patients $(40 \%)$ were affected by MDD, while 332 patients $(60.0 \%)$ were diagnosed with BD. The psychopathology groups did not significantly differ with regard to the proportion of suicide attempters: In the MDD group 77 $(34.8 \%)$ had a suicide attempt versus $136(40.9 \%)$ in the BD group $\left[\chi^{2}(1)=2.1, p=0.15\right]$, so we merged the two groups in our analysis.

Sociodemographic features of the sample, stratified by suicide attempt status, are reported in Table 1 . Suicide attempters were significantly younger than non-suicidal patients, and female patients were more likely to have attempted suicide in comparison with male ones. Mood disorder patients with low levels of education also had more suicide attempts compared with those with high educational background. Smoking habits (defined as the use of tobacco for a period of a month or more) were associated with suicide attempter status. The two groups did not significantly differ with regard to ethnicity or employment status, whereas a marginal significant difference $(p=0.05)$ was found with regard to marital status, wherein suicide attempters were less likely to be married or cohabiting.

\section{Clinical characteristics}

Clinical features of mood disorder episodes are described in Table 2a, stratified by suicide attempt status. Patients with positive anamnesis for suicide presented higher scores on HDRS and MADRS. Furthermore, we detected no association between suicide attempt and severity of the manic symptoms (YMRS). Suicide attempters also displayed poorer scores on functionality in working and studying activities, family and social life.

With regard to suicide attempt status and psychiatric comorbidities (Table 2b), we found an increased frequency of suicide attempters in mood disorder patients currently affected by anxiety disorders, in particular panic disorder, obsessive-compulsive disorder (OCD) and post-traumatic stress disorder (PTSD). The presence of any anxiety disorder was also associated with prior suicide attempts. With regard to physical disorders, there were no differences between suicide attempters and non-attempters on the prevalence of diabetes or thyroid disease (Table 2c). Finally, the presence of first- and second-degree relatives with suicidal behavior was associated with positive anamnesis for suicide attempt, whereas family history of bipolar or unipolar mood disorder was not (Table 2d).

As a last step, in a logistic regression model with age and gender as covariates, we tested which clinical factors are predictive of current suicidal risk. Due to high multicollinearity, three models were yielded, one including anxiety disorders as predictors, one with the rest of the clinical factors and one with the SDS, which highly correlated with the presence of both anxiety disorders and depressive symptoms and was entered in a regression as a single predictor. Besides age and gender, which were significant predictors, the presence of panic disorder, PTSD, severe depressive symptoms and high functional disability increased the odds of having a current suicide risk. Results are reported in Table 3. Mood disorder diagnosis (MDD or BD) was also entered as a predictor in all models but was not significant $(p>0.6)$ (data not shown).

\section{Genetic analyses}

Table 4 shows the frequency distributions of all SNPs of the four genes (COMT, BDNF, MAPK1 and CREB1) stratified by suicide attempt status. We found a significant association between MAPK1-rs13515 and suicide attempt status. Patients carrying the TT genotype were more likely to be suicide attempters, whereas the CC genotype was more frequent among non-attempters. Further analyses showed that this pattern was mainly observed in the male group, with significant differences between genotypes $\left[\chi^{2}(2)=11.60\right.$, $p=0.003]$, whereas in females differences did not approach significance $(p=0.10)$. Allelic analyses showed 
Table 1 Sociodemographic characteristics stratified by suicide attempt status, in the whole sample (MDD and BD patients)

\begin{tabular}{|c|c|c|c|c|c|c|}
\hline & \multicolumn{2}{|c|}{$\begin{array}{l}\text { Suicide attempt } \\
(n=213)\end{array}$} & $\begin{array}{l}\text { No suicide attempt } \\
(n=340)\end{array}$ & $t$ & $d f$ & $p$ value \\
\hline \multirow[t]{2}{*}{ Age $($ mean \pm SD) } & \multicolumn{2}{|c|}{$45.99 \pm 14.48$} & $48.88 \pm 13.75$ & -2.346 & 548 & 0.019 \\
\hline & & $N(\%)$ & $N(\%)$ & $\chi^{2}$ & $d f$ & $p$ value \\
\hline \multicolumn{7}{|l|}{ Gender } \\
\hline Females & & $150(70.8 \%)$ & $192(56.6 \%)$ & 11.042 & 1 & 0.001 \\
\hline \multicolumn{7}{|l|}{ Ethnicity } \\
\hline Caucasian & & $204(96.2 \%)$ & $325(95.9 \%)$ & 1.131 & 4 & 0.889 \\
\hline Asian & & $2(0.9 \%)$ & $2(0.6 \%)$ & & & \\
\hline African & & $5(2.4 \%)$ & $10(2.9 \%)$ & & & \\
\hline North American & & $0(0.0 \%)$ & $1(0.3 \%)$ & & & \\
\hline Latin-American & & $1(0.5 \%)$ & $2(0.3 \%)$ & & & \\
\hline \multicolumn{7}{|l|}{ Education $^{\mathrm{a}}$} \\
\hline Primary school & & $13(6.3 \%)$ & $20(6.0 \%)$ & 11.510 & 4 & 0.021 \\
\hline Secondary school & & $39(18.8 \%)$ & $35(10.4 \%)$ & & & \\
\hline Higher level seconda & y school & $57(27.4 \%)$ & $88(26.2 \%)$ & & & \\
\hline Non-university highe & education & $48(23.1 \%)$ & $113(33.6 \%)$ & & & \\
\hline University & & $51(24.5 \%)$ & $80(23.8 \%)$ & & & \\
\hline \multicolumn{7}{|l|}{ Marital status } \\
\hline Married/cohabiting & & $87(41.0 \%)$ & $172(50.7 \%)$ & 9.354 & 4 & 0.053 \\
\hline Widowed & & $6(2.8 \%)$ & $11(3.2 \%)$ & & & \\
\hline Separated & & $17(8.0 \%)$ & $12(3.5 \%)$ & & & \\
\hline Single & & $76(35.8 \%)$ & $100(29.5 \%)$ & & & \\
\hline Divorced & & $26(12.3 \%)$ & $44(13.0 \%)$ & & & \\
\hline \multicolumn{7}{|l|}{ Professional status } \\
\hline Employed (full time) & & $62(33.3 \%)$ & $135(44.4 \%)$ & 9.312 & 5 & 0.097 \\
\hline Employed (part time & & $23(12.4 \%)$ & $34(11.2 \%)$ & & & \\
\hline Unemployed & & $54(29.0 \%)$ & $81(26.6 \%)$ & & & \\
\hline Student & & $21(11.3 \%)$ & $18(5.9 \%)$ & & & \\
\hline Volunteer work & & $2(1.1 \%)$ & $1(0.3 \%)$ & & & \\
\hline Retired & & $24(12.9 \%)$ & $35(11.5 \%)$ & & & \\
\hline Smoking (for a mont & or more) & $133(63.9 \%)$ & $173(51.0 \%)$ & 8.717 & 1 & 0.003 \\
\hline
\end{tabular}

Significant $p$ values are in bold

$S D$ standard deviation, $d f$ degrees of freedom

a One patient was excluded due to the lack of information that the $\mathrm{T}$ allele was significantly more frequent among suicide attempters (frequency $=53 \%$ ) than among nonattempters (frequency $=42 \%$ ), $\left[\chi^{2}(1)=6.46, p=0.01\right]$. All other SNPs of the MAPK1 gene were not associated with suicide attempt status.

With regard to the CREB1 gene, we also found a significant association: The TC genotype of the rs6740584 was more frequent in suicide attempters, whereas the $\mathrm{CC}$ genotype was more frequent in non-attempters (Table 4). Further analyses showed that this pattern was most prevalent in females, where we found significant genotype differences $\left[\chi^{2}(2)=6.19, p=0.045\right]$, whereas in males differences did not reach significance $(p=0.10)$. Allelic analyses showed that the $\mathrm{T}$ allele of the same SNP was more frequent in suicide attempters, at the trend level of significance $\left[\chi^{2}(1)=3.12, p=0.08\right]$. The A allele of rs889895 was also more frequent among suicide attempters - the association reached only trend level of significance $\left[\chi^{2}(1)=3.09\right.$, $p=0.08]$. No association was found between suicide attempt status and the COMT Val158Met polymorphism, and neither with rs174696. Associations with all BDNF polymorphisms were also not significant.

\section{Discussion}

The present study explored several clinical and genetic factors in relation to suicide attempt history or current suicidal risk. History of a prior attempt is still considered one of the 
Table 2 Clinical characteristics, psychiatric comorbidities, physical diseases and family history stratified by suicide attempt status

\begin{tabular}{|c|c|c|c|c|c|c|}
\hline & \multicolumn{2}{|c|}{$\begin{array}{l}\text { Suicide attempt }(n=213) \\
\text { Mean } \pm \text { SD }\end{array}$} & $\begin{array}{l}\text { No suicide attempt }(n=340) \\
\text { Mean } \pm \text { SD }\end{array}$ & \multirow[t]{2}{*}{$t$} & \multirow[t]{2}{*}{$d f$} & $p$ value \\
\hline \multicolumn{5}{|l|}{ a. Clinical characteristics } & & \\
\hline Hamilton total score (21 items) & $15.95 \pm 9.10$ & \multicolumn{2}{|c|}{$13.73 \pm 8.29$} & 2.893 & 528 & 0.004 \\
\hline MADRS total score & $19.91 \pm 11.78$ & \multicolumn{2}{|c|}{$16.73 \pm 10.71$} & 3.202 & 528 & 0.001 \\
\hline YMRS total score & $3.51 \pm 5.81$ & \multicolumn{2}{|c|}{$4.11 \pm 6.36$} & -1.097 & 530 & 0.273 \\
\hline \multirow[t]{2}{*}{ Sheehan's Disability Scale } & $6.80 \pm 2.29$ & \multicolumn{2}{|c|}{$6.11 \pm 2.19$} & 3.473 & 534 & 0.001 \\
\hline & & $N(\%)$ & $N(\%)$ & $\chi^{2}$ & $d f$ & $p$ value \\
\hline \multicolumn{7}{|l|}{ b. Psychiatric comorbidities } \\
\hline \multicolumn{2}{|l|}{ Panic disorder } & $40(18.9 \%)$ & $37(11.0 \%)$ & 6.643 & 1 & 0.010 \\
\hline \multicolumn{2}{|l|}{ Obsessive-compulsive disorder ${ }^{\mathrm{a}}$} & $27(13.1 \%)$ & $25(7.5 \%)$ & 4.528 & 1 & 0.033 \\
\hline \multicolumn{2}{|l|}{ Social phobia } & $26(12.3 \%)$ & $33(9.8 \%)$ & 0.807 & 1 & 0.369 \\
\hline \multicolumn{2}{|l|}{ Post-traumatic stress disorder } & $22(10.4 \%)$ & $14(4.2 \%)$ & 8.225 & 1 & 0.004 \\
\hline \multicolumn{2}{|l|}{ Generalized anxiety disorder } & $66(31.1 \%)$ & $98(29.2 \%)$ & 0.239 & 1 & 0.625 \\
\hline \multicolumn{2}{|l|}{ Anorexia nervosa } & $2(0.9 \%)$ & $0(0.0 \%)$ & 3.166 & 1 & 0.075 \\
\hline \multicolumn{2}{|l|}{ Bulimia nervosa } & $4(1.9 \%)$ & $7(2.1 \%)$ & 0.028 & 1 & 0.867 \\
\hline \multicolumn{2}{|l|}{ Any anxiety disorder (current) } & $109(51.2 \%)$ & $138(40.6 \%)$ & 5.937 & 1 & 0.015 \\
\hline \multicolumn{2}{|l|}{ Alcohol abuse } & $48(22.5 \%)$ & $83(24.6 \%)$ & 0.294 & 1 & 0.587 \\
\hline \multicolumn{2}{|c|}{ Drug abuse } & $8(3.8 \%)$ & $10(3.0 \%)$ & 0.267 & 1 & 0.606 \\
\hline \multicolumn{2}{|c|}{ Mood disorder with psychotic features (lifetime) } & $81(38.6 \%)$ & $107(32.2 \%)$ & 2.284 & 1 & 0.131 \\
\hline \multicolumn{7}{|l|}{ c. Physical diseases } \\
\hline \multicolumn{7}{|l|}{ Thyroid disease } \\
\hline \multicolumn{2}{|l|}{ Hyperthyroidism } & $3(1.4 \%)$ & $3(0.9 \%)$ & 1.24 & 3 & 0.742 \\
\hline \multicolumn{2}{|l|}{ Hypothyroidism } & $23(11.1 \%)$ & $29(8.7 \%)$ & & & \\
\hline \multicolumn{2}{|l|}{ Thyroid goiter } & $3(1.4 \%)$ & $4(1.2 \%)$ & & & \\
\hline \multicolumn{2}{|l|}{ Diabetes } & $7(3.4 \%)$ & $15(4.5 \%)$ & 0.43 & 1 & 0.51 \\
\hline \multicolumn{7}{|l|}{ d. Familial history } \\
\hline \multicolumn{2}{|l|}{ MDD in first-degree relatives ${ }^{\mathrm{a}}$} & $128(66.7 \%)$ & $183(61.0 \%)$ & 1.617 & 1 & 0.204 \\
\hline $\mathrm{BD}$ in first-degree relatives ${ }^{\mathrm{a}}$ & & $51(30.4 \%)$ & $72(25.4 \%)$ & 1.284 & 1 & 0.257 \\
\hline Suicide attempt in first- and seco & egree relatives ${ }^{\mathrm{a}}$ & $58(36.0 \%)$ & $59(22.2 \%)$ & 9.664 & 1 & 0.002 \\
\hline
\end{tabular}

Significant $p$ values are in bold

$d f$ degrees of freedom, $S D$ standard deviation, MADRS Montgomery-Asberg Depression Rating Scale, YMRS Young Mania Rating Scale

${ }^{a}$ Patients were excluded due to the lack of information. All disorders are assessed as current unless otherwise specified

best predictors of future suicide [28]. Our analyses add to the prior literature by confirming several associations of factors related to a suicidal profile in a relatively large sample of mood disorder patients.

More specifically, with regard to age, our findings are in line with prior research, demonstrating the presence of higher suicide rates in younger patients, in both MDD [92, $93]$ and BD $[30,94]$. This can be explained by the association of early-onset affective disorders with more severe depressive symptoms and increased liability toward suicide [12], while in older patients somatic symptoms and cognitive decline prevail [93]. Female patients had a higher suicide attempt rate, in line with prior literature. In fact, women often present non-suicidal self-injury [10], while in men suicidal behavior is frequently characterized by violent methods and higher lethality [9]. In addition, bipolar women are more likely to display predominance of depressive polarity [9], a known risk factor for suicidality [28]. Nonetheless, another hypothesis has been proposed: Depressive status in females could be influenced by hormone-brain associations [95]. In particular, pubertal hormonal changes may contribute to sensitize brain structures toward neurobiological and behavioral repercussions of exposure to stress, which is known to be involved in the pathophysiology of depressive mood [96]. With regard to education, patients with lower education were more likely to report history of suicide; this is probably related to poorer social and occupational functioning, in conjunction 
Table 3 Logistic regression models examining predictors of current suicidal risk

\begin{tabular}{|c|c|c|c|c|c|c|}
\hline & \multirow[t]{2}{*}{ B } & \multirow[t]{2}{*}{ SE } & \multirow[t]{2}{*}{$p$ value } & \multirow[t]{2}{*}{ OR } & \multicolumn{2}{|c|}{$95 \% \mathrm{CI}$ for OR } \\
\hline & & & & & Lower & Upper \\
\hline \multicolumn{7}{|c|}{ Model 1: logistic regression including sociodemographics and anxiety disorders as predictors } \\
\hline Age & -0.014 & 0.007 & $\mathbf{0 . 0 3 3}$ & 0.986 & 0.973 & 0.999 \\
\hline Gender & 0.441 & 0.193 & 0.022 & 1.555 & 1.064 & 2.270 \\
\hline Education & 0.022 & 0.079 & 0.783 & 1.022 & 0.875 & 1.194 \\
\hline Panic disorder & 1.276 & 0.358 & $<0.001$ & 3.583 & 1.775 & 7.232 \\
\hline Obsessive-compulsive disorder & 0.810 & 0.414 & 0.051 & 2.248 & 0.998 & 5.062 \\
\hline Post-traumatic stress disorder & 1.099 & 0.557 & 0.049 & 3.001 & 1.007 & 8.942 \\
\hline \multicolumn{7}{|c|}{$\begin{array}{l}\text { Model 2: logistic regression including sociodemographics, depressive symptoms and family history as } \\
\text { predictors }\end{array}$} \\
\hline Age & -0.022 & 0.009 & 0.012 & 0.979 & 0.962 & 0.995 \\
\hline Gender & 0.304 & 0.233 & 0.191 & 1.355 & 0.859 & 2.138 \\
\hline Education & 0.053 & 0.096 & 0.577 & 1.055 & 0.874 & 1.273 \\
\hline Smoke & 0.427 & 0.232 & 0.065 & 1.532 & 0.973 & 2.413 \\
\hline Hamilton total score & 0.106 & 0.015 & $<0.001$ & 1.112 & 1.079 & 1.146 \\
\hline Familial history of suicide attempt & 0.156 & 0.269 & 0.562 & 1.168 & 0.690 & 1.978 \\
\hline \multicolumn{7}{|c|}{ Model 3: logistic regression including sociodemographics Sheehan's Disability Scale as predictor } \\
\hline Age & -0.019 & 0.007 & 0.005 & 0.981 & 0.968 & 0.994 \\
\hline Gender & 0.405 & 0.194 & $\mathbf{0 . 0 3 7}$ & 1.500 & 1.025 & 2.194 \\
\hline Education & 0.074 & 0.080 & 0.354 & 1.077 & 0.921 & 1.259 \\
\hline Sheehan (mean) & 0.222 & 0.043 & $<0.001$ & 1.248 & 1.147 & 1.358 \\
\hline
\end{tabular}

Significant predictors are in bold with an earlier-onset mood disorder and early behavioral dysfunction [97]. Past suicide attempters were more likely to be current smokers, and this is also in line with other studies $[8,98]$.

With regard to clinical characteristics that are associated with suicide, we found higher depression severity in the suicide attempters group, consistently with recent literature $[13,20,28]$ that indicates symptoms like hopelessness and longer periods spent in depressed mood as substantial risk factors for suicidality. In fact, suicide attempts in BD are more likely to occur during depressive and mixed phases of the illness [30]. Consistent with this, we did not observe any differences in the levels of manic symptoms. A higher degree of disability was observed in the suicide group, in line with other findings [99], and can be probably ascribed to a more severe clinical course of the disorder (including high comorbidity) and treatment-resistant traits. Indeed, patients with history of a suicide attempt were more likely to suffer from a comorbid panic disorder, PTSD and OCD. High disorder comorbidity in suicide samples has been reported before in both depressed and bipolar patients [20, 23]; in particular, OCD [28] and obsessive-compulsive personality traits [1] have been associated with suicidal behavior. Comorbidity with panic disorder and PTSD was also associated with a significant increase in current suicidal risk in our sample: Our findings are in line with a large-scale longitudinal study showing that patients affected by mood disorders and comorbid anxiety have an increased risk of a subsequent suicide attempt [100]. Mood disorder patients affected by comorbid anxiety are more susceptible to present earlier onset of symptoms [101], increased recurrence of depressive episodes [102] and severe depressive psychopathology [103]. Seeking auto-medication by means of alcohol and substance abuse [104, 105] may also elicit an additive risk on suicide outcome [101]. Finally, family history of suicide was associated indeed with a higher likelihood of having attempted suicide, in line with prior observations [106]. Interestingly, family history of BD or MDD was not associated with a suicide attempt status. Prior literature shows evidence of an increased frequency of psychiatric conditions in the family of patients who committed suicide $[107,108]$ and in the family of attempters [106]; our observations are in the same direction but did not reach statistical significance. Our sample size has adequate power; thus, we conclude that prior psychiatric family history is not strongly associated with suicide attempt status in mood disorder patients, but family history of suicide is. We should also note that in our sample the percentage of suicide attempters in the MDD and BD groups did not differ significantly, which is contrary to prior observations that show higher suicide attempter rates in BD patients [109, 110]; however, no differences between the two groups have also been found [111].

Turning to the associations with genetic polymorphisms, we found no association between the COMT Val158Met 
Table 4 Distribution of genotypes on the four genes (COMT, BDNF, MAPK1 and CREB1) according to suicide attempt status

\begin{tabular}{|c|c|c|c|c|}
\hline & $\begin{array}{l}\text { Suicide attempt } \\
N(\%)\end{array}$ & $\begin{array}{l}\text { No suicide } \\
\text { attempt } N(\%)\end{array}$ & $\chi^{2}$ & $p$ value \\
\hline \multicolumn{5}{|c|}{ COMT } \\
\hline \multicolumn{5}{|c|}{ rs4680 } \\
\hline AA & $23(23.2 \%)$ & $39(26.7 \%)$ & 1.202 & 0.548 \\
\hline GA & $44(44.4 \%)$ & $69(47.3 \%)$ & & \\
\hline GG & $32(32.3 \%)$ & $38(26.0 \%)$ & & \\
\hline \multicolumn{5}{|c|}{ rs174696 } \\
\hline $\mathrm{CC}$ & $3(2.9 \%)$ & $2(1.4 \%)$ & 3.702 & 0.157 \\
\hline $\mathrm{CT}$ & $41(39.8 \%)$ & $44(29.9 \%)$ & & \\
\hline $\mathrm{TT}$ & $59(57.3 \%)$ & $101(68.7 \%)$ & & \\
\hline \multicolumn{5}{|c|}{$B D N F$} \\
\hline \multicolumn{5}{|c|}{ rs6265 } \\
\hline AA & $3(3.1 \%)$ & $5(3.5 \%)$ & 0.379 & 0.827 \\
\hline GA & $25(25.8 \%)$ & $41(29.1 \%)$ & & \\
\hline GG & $69(71.1 \%)$ & $95(67.4 \%)$ & & \\
\hline \multicolumn{5}{|c|}{ rs11030101 } \\
\hline AA & $25(24.0 \%)$ & $38(25.7 \%)$ & 0.791 & 0.673 \\
\hline TA & $53(51.0 \%)$ & $80(54.1 \%)$ & & \\
\hline TT & $26(25.0 \%)$ & $30(20.3 \%)$ & & \\
\hline \multicolumn{5}{|c|}{ rs11030104 } \\
\hline AA & $63(61.8 \%)$ & $85(58.6 \%)$ & 0.248 & 0.883 \\
\hline AG & $35(34.3 \%)$ & $54(37.2 \%)$ & & \\
\hline GG & $4(3.9 \%)$ & $6(4.1 \%)$ & & \\
\hline \multicolumn{5}{|c|}{ rs12273363 } \\
\hline $\mathrm{CC}$ & $3(2.9 \%)$ & $3(2.0 \%)$ & 0.259 & 0.878 \\
\hline $\mathrm{TC}$ & $25(24.0 \%)$ & $38(25.7 \%)$ & & \\
\hline $\mathrm{TT}$ & $76(73.1 \%)$ & $107(72.3 \%)$ & & \\
\hline \multicolumn{5}{|c|}{ MAPK1 } \\
\hline \multicolumn{5}{|c|}{ rs6928 } \\
\hline $\mathrm{CC}$ & $31(30.4 \%)$ & $42(28.0 \%)$ & 1.091 & 0.580 \\
\hline $\mathrm{GC}$ & $43(42.2 \%)$ & $73(48.7 \%)$ & & \\
\hline GG & $28(27.5 \%)$ & $35(23.3 \%)$ & & \\
\hline \multicolumn{5}{|c|}{ rs3810608 } \\
\hline AA & $18(17.1 \%)$ & $17(11.7 \%)$ & 1.872 & 0.392 \\
\hline AG & $29(27.6 \%)$ & $48(33.1 \%)$ & & \\
\hline GG & $58(55.2 \%)$ & $80(55.2 \%)$ & & \\
\hline \multicolumn{5}{|c|}{ rs 13515} \\
\hline $\mathrm{CC}$ & $14(13.3 \%)$ & $42(28.4 \%)$ & 9.240 & 0.010 \\
\hline $\mathrm{TC}$ & $70(66.7 \%)$ & $88(59.5 \%)$ & & \\
\hline TT & $21(20.0 \%)$ & $18(12.2 \%)$ & & \\
\hline \multicolumn{5}{|c|}{ rs8136867 } \\
\hline AA & $7(7.6 \%)$ & $12(8.6 \%)$ & 0.357 & 0.837 \\
\hline GA & $23(25.0 \%)$ & $39(27.9 \%)$ & & \\
\hline GG & $62(67.4 \%)$ & $89(63.6 \%)$ & & \\
\hline \multicolumn{5}{|c|}{ CREBI } \\
\hline \multicolumn{5}{|c|}{ rs889895 } \\
\hline AA & $63(61.2 \%)$ & $71(50.0 \%)$ & 3.003 & 0.223 \\
\hline AG & $27(26.2 \%)$ & $48(33.8 \%)$ & & \\
\hline
\end{tabular}

Table 4 continued

\begin{tabular}{llcll}
\hline & $\begin{array}{l}\text { Suicide attempt } \\
N(\%)\end{array}$ & $\begin{array}{l}\text { No suicide } \\
\text { attempt } N(\%)\end{array}$ & $\chi^{2}$ & $p$ value \\
\hline GG & $13(12.6 \%)$ & $23(16.2 \%)$ & & \\
rs2254137 & & & & \\
AA & $32(30.2 \%)$ & $42(28.0 \%)$ & 5.202 & 0.074 \\
CA & $47(44.3 \%)$ & $85(56.7 \%)$ & & \\
CC & $27(25.5 \%)$ & $23(15.3 \%)$ & & \\
rs6740584 & & & & \\
CC & $7(6.7 \%)$ & $31(20.8 \%)$ & 9.694 & $\mathbf{0 . 0 0 8}$ \\
TC & $70(67.3 \%)$ & $82(55.0 \%)$ & & \\
TT & $27(26.0 \%)$ & $36(24.2 \%)$ & & \\
rs2551922 & & & & \\
AA & $1(0.9 \%)$ & 0.455 \\
GA & $7(6.6 \%)$ & $12(7.9 \%)$ & & \\
GG & $98(92.5 \%)$ & $140(92.1 \%)$ & & \\
\hline
\end{tabular}

Significant $p$ values are in bold

polymorphism and history of suicide attempt, in line with negative findings from prior literature [45-48], supporting the hypothesis of an indirect modulation exerted by COMT through perhaps intermediate phenotypes that may increase the vulnerability toward suicidal behavior [39]. In fact, several studies linked rs4680 to anger, aggressive and violent temperamental traits [51, 52], reward dependence [45] and novelty seeking/extraversion [49].

We also did not find any associations with the BDNF gene polymorphisms. A view of the literature shows mixed results: Some studies provide evidence of association between suicide and reduced levels of serum BDNF [112], along with a decrease in BDNF mRNA expression [56, 113]. We found dissimilar results pertaining to the role of Val66Met in increasing suicidal risk [64, 65, 114, 115]. It has to be noted that although the majority of these studies point toward an association with suicidal behavior, negative studies are less likely to be published, resulting in publication bias.

To our knowledge, this is the first study suggesting an association of rs13515 (within MAPK1) and rs6740584 (within CREB1) polymorphisms with suicide attempt in a sample of bipolar patients. A study conducted by Dwivedi [73] offers an accurate insight of the physiopathologic mechanism involving MAPK1/ERK1 pathway. Previous research showed that expression and activation of extracellular signal-regulated kinase (ERK1/2) were lower in prefrontal cortex and hippocampus of suicide subjects affected by MDD [116]; the down-regulation was found to be associated with a decrease in ERK1/2 mRNA and protein levels. Studies conducted in rodents support these results, showing that the administration of a compound which blocks activation of ERK1/2 produces mood 
disorder-related behavioral deficits [117], and that depressive-like behavior is related to decreased levels of ERK1/2 phosphorylation [75]. Our hypothesis is that a genetic variation of rs13515 within the 5'-UTR of MAPK1 gene, in particular the presence of TT genotype, could influence mRNA transduction, leading to a decrease in ERK1/2 synthesis. The subsequent down-regulation of MAPK/ERK1 signaling cascade may result in functional abnormalities within the prefrontal cortex and hippocampal regions of the brain, such as dysregulation in neuronal proliferation, synaptic plasticity and inflammatory responses.

The present report has several limitations. First of all, it is a cross-sectional study, not allowing for the deduction of causal relationships. Secondly, suicide risk was classified as a dichotomous trait, according to the presence or absence of a past suicide attempt. We chose to do so because history of a suicide attempt is a more stable risk trait [28] than current suicidal ideation, according to prior literature. However, we may have missed cases who have a high suicidal risk but have not performed an attempt before. Regarding the genetic results, the number of cases in our study may be low, therefore not providing enough power to detect significant associations, for example, with the BDNF/COMT genes. Also, major effects from single SNPs are unlikely [118]. Future meta-analyses will shed light on this matter. Positive results involving SNPs within MAPK1 and CREB1 genes (also the gender-specific findings) should be considered as preliminary and are worthy of future investigation. Finally, no correction for multiple testing was applied despite the high number of investigated variables; most results would not survive correction. However, given the exploratory nature of our study, we do not claim to report strong associations but only suggestive results which could be useful for further investigations or meta-analyses.

\section{Conclusion}

Suicidal behavior has a complex etiology, involving both genetic predisposition and exposure to environmental influences, aside from the presence of an underlying psychiatric diagnosis. Our study provided suggestive data of variants within MAPK1 and CREB1 genes associated with suicide attempt status, whereas associations with variations in the COMT and BDNF Val/Met polymorphisms were not replicated in this sample. From a clinical perspective, our study proposes several clinical characteristics, such as increased depressive symptomatology, anxiety comorbidity, functional disability and family history of suicidality, as correlates associated with a suicide attempt status in a large sample of mood disorder patients. Current suicidal risk was also predicted by most of these factors, but current anxiety comorbidity increased the odds most significantly. Clinicians may consider these determinants in their treatment agenda, in order to monitor such clinical factors and administer adequate therapeutic interventions to prevent recurrence of suicidal tendencies.

\section{Compliance with ethical standards}

Conflict of interest Prof. Serretti is or has been consultant/speaker for: Abbott, Angelini, Astra Zeneca, Clinical Data, Boheringer, Bristol-Myers Squibb, Eli Lilly, GlaxoSmithKline, Italfarmaco, Janssen, Lundbeck, Pfizer, Sanofi, Servier. Dr. Souery has received grant/ research support from GlaxoSmithKline and Lundbeck and has served as a consultant or on advisory boards for AstraZeneca, Bristol-Myers Squibb, Eli Lilly, Janssen and Lundbeck. Prof. Mendlewicz is a member of the Board of the Lundbeck International Neuroscience Foundation and of Advisory Board of Servier. The other authors report no conflict of interest.

\section{References}

1. Lester D, Abdel-Khalek AM (1999) Manic-depression, suicidality, and obsessive-compulsive tendencies. Psychol Rep 85:1100

2. Moffitt TE, Caspi A, Taylor A, Kokaua J, Milne BJ, Polanczyk G, Poulton R (2010) How common are common mental disorders? Evidence that lifetime prevalence rates are doubled by prospective versus retrospective ascertainment. Psychol Med 40:899-909

3. Tsuang MT, Taylor L, Faraone SV (2004) An overview of the genetics of psychotic mood disorders. J Psychiatr Res 38:3-15

4. Harris EC, Barraclough B (1997) Suicide as an outcome for mental disorders. A meta-analysis. Br J Psychiatry 170:205-228

5. Conwell Y, Duberstein PR, Cox C, Herrmann JH, Forbes NT, Caine ED (1996) Relationships of age and Axis I diagnoses in victims of completed suicide: a psychological autopsy study. Am J Psychiatry 153:1001-1008

6. Chen YW, Dilsaver SC (1996) Lifetime rates of suicide attempts among subjects with bipolar and unipolar disorders relative to subjects with other Axis I disorders. Biol Psychiatry 39:896-899

7. Angst J, Hengartner MP, Gamma A, von Zerssen D, Angst F (2013) Mortality of 403 patients with mood disorders 48 to 52 years after their psychiatric hospitalisation. Eur Arch Psychiatry Clin Neurosci 263:425-434

8. Oquendo MA, Galfalvy H, Russo S, Ellis SP, Grunebaum MF, Burke A, Mann JJ (2004) Prospective study of clinical predictors of suicidal acts after a major depressive episode in patients with major depressive disorder or bipolar disorder. Am J Psychiatry 161:1433-1441

9. Nivoli AM, Pacchiarotti I, Rosa AR, Popovic D, Murru A, Valenti M, Bonnin CM, Grande I, Sanchez-Moreno J, Vieta E, Colom F (2011) Gender differences in a cohort study of 604 bipolar patients: the role of predominant polarity. J Affect Disord 133:443-449

10. Victor SE, Klonsky ED (2014) Correlates of suicide attempts among self-injurers: a meta-analysis. Clin Psychol Rev 34:282-297

11. Angst J, Hengartner MP, Rogers J, Schnyder U, Steinhausen HC, Ajdacic-Gross V, Rossler W (2014) Suicidality in the prospective Zurich study: prevalence, risk factors and gender. Eur Arch Psychiatry Clin Neurosci 264:557-565 
12. Coryell W, Fiedorowicz J, Leon AC, Endicott J, Keller MB (2013) Age of onset and the prospectively observed course of illness in bipolar disorder. J Affect Disord 146:34-38

13. Goldstein TR, Ha W, Axelson DA, Goldstein BI, Liao F, Gill MK, Ryan ND, Yen S, Hunt J, Hower H, Keller M, Strober M, Birmaher B (2012) Predictors of prospectively examined suicide attempts among youth with bipolar disorder. Arch Gen Psychiatry 69:1113-1122

14. Altamura AC, Dell'Osso B, Berlin HA, Buoli M, Bassetti R, Mundo E (2010) Duration of untreated illness and suicide in bipolar disorder: a naturalistic study. Eur Arch Psychiatry Clin Neurosci 260:385-391

15. Seemuller F, Meier S, Obermeier M, Musil R, Bauer M, Adli M, Kronmuller K, Holsboer F, Brieger P, Laux G, Bender W, Heuser I, Zeiler J, Gaebel W, Riedel M, Falkai P, Moller HJ (2014) Three-year long-term outcome of 458 naturalistically treated inpatients with major depressive episode: severe relapse rates and risk factors. Eur Arch Psychiatry Clin Neurosci 264:567-575

16. Hawton K, Sutton L, Haw C, Sinclair J, Harriss L (2005) Suicide and attempted suicide in bipolar disorder: a systematic review of risk factors. J Clin Psychiatry 66:693-704

17. Acosta FJ, Vega D, Torralba L, Navarro S, Ramallo-Farina Y, Fiuza D, Hernandez JL, Siris SG (2012) Hopelessness and suicidal risk in bipolar disorder. A study in clinically nonsyndromal patients. Compr Psychiatry 53:1103-1109

18. Coryell W, Young EA (2005) Clinical predictors of suicide in primary major depressive disorder. J Clin Psychiatry 66:412-417

19. Mann JJ, Waternaux C, Haas GL, Malone KM (1999) Toward a clinical model of suicidal behavior in psychiatric patients. Am J Psychiatry 156:181-189

20. Hawton K, Casanas ICC, Haw C, Saunders K (2013) Risk factors for suicide in individuals with depression: a systematic review. J Affect Disord 147:17-28

21. Valtonen HM, Suominen K, Mantere O, Leppamaki S, Arvilommi P, Isometsa E (2007) Suicidal behaviour during different phases of bipolar disorder. J Affect Disord 97:101-107

22. Statham DJ, Heath AC, Madden PA, Bucholz KK, Bierut L, Dinwiddie SH, Slutske WS, Dunne MP, Martin NG (1998) Suicidal behaviour: an epidemiological and genetic study. Psychol Med 28:839-855

23. Baldassano CF (2006) Illness course, comorbidity, gender, and suicidality in patients with bipolar disorder. J Clin Psychiatry 67(Suppl 11):8-11

24. Neves FS, Malloy-Diniz LF, Barbosa IG, Brasil PM, Correa H (2009) Bipolar disorder first episode and suicidal behavior: are there differences according to type of suicide attempt? Rev Bras Psiquiatr 31:114-118

25. Finseth PI, Morken G, Andreassen OA, Malt UF, Vaaler AE (2012) Risk factors related to lifetime suicide attempts in acutely admitted bipolar disorder inpatients. Bipolar Disord 14:727-734

26. Beghi M, Rosenbaum JF, Cerri C, Cornaggia CM (2013) Risk factors for fatal and nonfatal repetition of suicide attempts: a literature review. Neuropsychiatr Dis Treat 9:1725-1736

27. Nordstrom P, Asberg M, Aberg-Wistedt A, Nordin C (1995) Attempted suicide predicts suicide risk in mood disorders. Acta Psychiatr Scand 92:345-350

28. Antypa N, Antonioli M, Serretti A (2013) Clinical, psychological and environmental predictors of prospective suicide events in patients with bipolar disorder. J Psychiatr Res 47:1800-1808

29. McElroy SL, Frye MA, Hellemann G, Altshuler L, Leverich GS, Suppes T, Keck PE, Nolen WA, Kupka R, Post RM (2011) Prevalence and correlates of eating disorders in 875 patients with bipolar disorder. J Affect Disord 128:191-198
30. Simpson SG, Jamison KR (1999) The risk of suicide in patients with bipolar disorders. J Clin Psychiatry 60(Suppl 2):53-56 (discussion 75-56, 113-116)

31. Pompili M, Serafini G, Innamorati M, Biondi M, Siracusano A, Di Giannantonio M, Giupponi G, Amore M, Lester D, Girardi P, Moller-Leimkuhler AM (2012) Substance abuse and suicide risk among adolescents. Eur Arch Psychiatry Clin Neurosci 262(6):469-485

32. Dumais A, Lesage AD, Alda M, Rouleau G, Dumont M, Chawky N, Roy M, Mann JJ, Benkelfat C, Turecki G (2005) Risk factors for suicide completion in major depression: a casecontrol study of impulsive and aggressive behaviors in men. Am J Psychiatry 162:2116-2124

33. Maser JD, Akiskal HS, Schettler P, Scheftner W, Mueller T, Endicott J, Solomon D, Clayton P (2002) Can temperament identify affectively ill patients who engage in lethal or nearlethal suicidal behavior? A 14-year prospective study. Suicide Life Threat Behav 32:10-32

34. McGuffin P, Marusic A, Farmer A (2001) What can psychiatric genetics offer suicidology? Crisis 22:61-65

35. Bortolato M, Pivac N, Muck Seler D, Nikolac Perkovic M, Pessia M, Di Giovanni G (2013) The role of the serotonergic system at the interface of aggression and suicide. Neuroscience 236:160-185

36. Joiner TE Jr, Brown JS, Wingate LR (2005) The psychology and neurobiology of suicidal behavior. Annu Rev Psychol 56:287-314

37. Antypa N, Serretti A, Rujescu D (2013) Serotonergic genes and suicide: a systematic review. Eur Neuropsychopharmacol 23:1125-1142

38. Stanley B, Molcho A, Stanley M, Winchel R, Gameroff MJ, Parsons B, Mann JJ (2000) Association of aggressive behavior with altered serotonergic function in patients who are not suicidal. Am J Psychiatry 157:609-614

39. Mann JJ, Arango VA, Avenevoli S, Brent DA, Champagne FA, Clayton P, Currier D, Dougherty DM, Haghighi F, Hodge SE, Kleinman J, Lehner T, McMahon F, Moscicki EK, Oquendo MA, Pandey GN, Pearson J, Stanley B, Terwilliger J, Wenzel A (2009) Candidate endophenotypes for genetic studies of suicidal behavior. Biol Psychiatry 65:556-563

40. Rujescu D, Giegling I (2010) The genetics of neurosystems in mental ill-health and suicidality: beyond serotonin. Eur Psychiatry $25: 272-274$

41. Lachman HM, Papolos DF, Saito T, Yu YM, Szumlanski CL, Weinshilboum RM (1996) Human catechol-O-methyltransferase pharmacogenetics: description of a functional polymorphism and its potential application to neuropsychiatric disorders. Pharmacogenetics 6:243-250

42. Chen J, Lipska BK, Halim N, Ma QD, Matsumoto M, Melhem S, Kolachana BS, Hyde TM, Herman MM, Apud J, Egan MF, Kleinman JE, Weinberger DR (2004) Functional analysis of genetic variation in catechol-O-methyltransferase (COMT): effects on mrna, protein, and enzyme activity in postmortem human brain. Am J Hum Genet 75:807-821

43. Antypa N, Drago A, Serretti A (2013) The role of COMT gene variants in depression: bridging neuropsychological, behavioral and clinical phenotypes. Neurosci Biobehav Rev 37:1597-1610

44. Kia-Keating BM, Glatt SJ, Tsuang MT (2007) Meta-analyses suggest association between COMT, but not HTR1B, alleles, and suicidal behavior. Am J Med Genet B Neuropsychiatr Genet 144B:1048-1053

45. Calati R, Porcelli S, Giegling I, Hartmann AM, Moller HJ, De Ronchi D, Serretti A, Rujescu D (2011) Catechol-O-methyltransferase gene modulation on suicidal behavior and personality traits: review, meta-analysis and association study. J Psychiatr Res 45:309-321 
46. De Luca V, Strauss J, Kennedy JL (2008) Power based association analysis (PBAT) of serotonergic and noradrenergic polymorphisms in bipolar patients with suicidal behaviour. Prog Neuropsychopharmacol Biol Psychiatry 32:197-203

47. Zalsman G, Huang YY, Oquendo MA, Brent DA, Giner L, Haghighi F, Burke AK, Ellis SP, Currier D, Mann JJ (2008) No association of COMT Val158Met polymorphism with suicidal behavior or CSF monoamine metabolites in mood disorders. Arch Suicide Res 12:327-335

48. Schosser A, Calati R, Serretti A, Massat I, Kocabas NA, Papageorgiou K, Linotte S, Mendlewicz J, Souery D, Zohar J, Juven-Wetzler A, Montgomery S, Kasper S (2012) The impact of COMT gene polymorphisms on suicidality in treatment resistant major depressive disorder-a European multicenter study. Eur Neuropsychopharmacol 22:259-266

49. Golimbet VE, Alfimova MV, Gritsenko IK, Ebstein RP (2007) Relationship between dopamine system genes and extraversion and novelty seeking. Neurosci Behav Physiol 37:601-606

50. Hoth KF, Paul RH, Williams LM, Dobson-Stone C, Todd E, Schofield PR, Gunstad J, Cohen RA, Gordon E (2006) Associations between the COMT Val/Met polymorphism, early life stress, and personality among healthy adults. Neuropsychiatr Dis Treat 2:219-225

51. Kulikova MA, Maluchenko NV, Timofeeva MA, Shlepzova VA, Schegolkova JV, Sysoeva OV, Ivanitsky AM, Tonevitsky AG (2008) Effect of functional catechol-O-methyltransferase Val158Met polymorphism on physical aggression. Bull Exp Biol Med 145:62-64

52. Rujescu D, Giegling I, Gietl A, Hartmann AM, Moller HJ (2003) A functional single nucleotide polymorphism (V158M) in the COMT gene is associated with aggressive personality traits. Biol Psychiatry 54:34-39

53. Hong JP, Lee JS, Chung S, Jung J, Yoo HK, Chang SM, Kim CY (2008) New functional single nucleotide polymorphism (Ala72Ser) in the COMT gene is associated with aggressive behavior in male schizophrenia. Am J Med Genet B Neuropsychiatr Genet 147B:658-660

54. Soyka M (2011) Neurobiology of aggression and violence in schizophrenia. Schizophr Bull 37:913-920

55. Dwivedi Y (2010) Brain-derived neurotrophic factor and suicide pathogenesis. Ann Med 42:87-96

56. Dwivedi Y, Rizavi HS, Conley RR, Roberts RC, Tamminga CA, Pandey GN (2003) Altered gene expression of brain-derived neurotrophic factor and receptor tyrosine kinase B in postmortem brain of suicide subjects. Arch Gen Psychiatry 60:804-815

57. Sen S, Duman R, Sanacora G (2008) Serum brain-derived neurotrophic factor, depression, and antidepressant medications: meta-analyses and implications. Biol Psychiatry 64:527-532

58. Piccinni A, Marazziti D, Catena M, Domenici L, Del Debbio A, Bianchi C, Mannari C, Martini C, Da Pozzo E, Schiavi E, Mariotti A, Roncaglia I, Palla A, Consoli G, Giovannini L, Massimetti G, Dell'Osso L (2008) Plasma and serum brain-derived neurotrophic factor (BDNF) in depressed patients during 1 year of antidepressant treatments. J Affect Disord 105:279-283

59. Chen ZY, Patel PD, Sant G, Meng CX, Teng KK, Hempstead BL, Lee FS (2004) Variant brain-derived neurotrophic factor (BDNF) (Met66) alters the intracellular trafficking and activitydependent secretion of wild-type BDNF in neurosecretory cells and cortical neurons. J Neurosci 24:4401-4411

60. Liu L, Foroud T, Xuei X, Berrettini W, Byerley W, Coryell W, El-Mallakh R, Gershon ES, Kelsoe JR, Lawson WB, MacKinnon DF, McInnis M, McMahon FJ, Murphy DL, Rice J, Scheftner W, Zandi PP, Lohoff FW, Niculescu AB, Meyer ET, Edenberg HJ, Nurnberger JI Jr (2008) Evidence of association between brain-derived neurotrophic factor gene and bipolar disorder. Psychiatr Genet 18:267-274
61. Lohoff FW, Sander T, Ferraro TN, Dahl JP, Gallinat J, Berrettini WH (2005) Confirmation of association between the Val66Met polymorphism in the brain-derived neurotrophic factor (BDNF) gene and bipolar I disorder. Am J Med Genet B Neuropsychiatr Genet 139B:51-53

62. Green EK, Raybould R, Macgregor S, Hyde S, Young AH, O’Donovan MC, Owen MJ, Kirov G, Jones L, Jones I, Craddock N (2006) Genetic variation of brain-derived neurotrophic factor (BDNF) in bipolar disorder: case-control study of over 3000 individuals from the UK. Br J Psychiatry 188:21-25

63. Muller DJ, de Luca V, Sicard T, King N, Strauss J, Kennedy JL (2006) Brain-derived neurotrophic factor (BDNF) gene and rapid-cycling bipolar disorder: family-based association study. Br J Psychiatry 189:317-323

64. Kim B, Kim CY, Hong JP, Kim SY, Lee C, Joo YH (2008) Brain-derived neurotrophic factor Val/Met polymorphism and bipolar disorder. Association of the met allele with suicidal behavior of bipolar patients. Neuropsychobiology 58:97-103

65. Zai CC, Manchia M, De Luca V, Tiwari AK, Chowdhury NI, Zai GC, Tong RP, Yilmaz Z, Shaikh SA, Strauss J, Kennedy JL (2012) The brain-derived neurotrophic factor gene in suicidal behaviour: a meta-analysis. Int J Neuropsychopharmacol 15:1037-1042

66. Sarchiapone M, Carli V, Roy A, Iacoviello L, Cuomo C, Latella MC, di Giannantonio M, Janiri L, de Gaetano M, Janal MN (2008) Association of polymorphism (Val66Met) of brainderived neurotrophic factor with suicide attempts in depressed patients. Neuropsychobiology 57:139-145

67. Schenkel LC, Segal J, Becker JA, Manfro GG, Bianchin MM, Leistner-Segal S (2010) The BDNF Val66Met polymorphism is an independent risk factor for high lethality in suicide attempts of depressed patients. Prog Neuropsychopharmacol Biol Psychiatry 34:940-944

68. Niitsu T, Fabbri C, Bentini F, Serretti A (2013) Pharmacogenetics in major depression: a comprehensive meta-analysis. Prog Neuropsychopharmacol Biol Psychiatry 45:183-194

69. Pae CU, Chiesa A, Porcelli S, Han C, Patkar AA, Lee SJ, Park MH, Serretti A, De Ronchi D (2012) Influence of BDNF variants on diagnosis and response to treatment in patients with major depression, bipolar disorder and schizophrenia. Neuropsychobiology 65:1-11

70. Chen Z, Gibson TB, Robinson F, Silvestro L, Pearson G, Xu B, Wright A, Vanderbilt C, Cobb MH (2001) Map kinases. Chem Rev 101:2449-2476

71. Sweatt JD (2001) The neuronal map kinase cascade: a biochemical signal integration system subserving synaptic plasticity and memory. J Neurochem 76:1-10

72. Bogoyevitch MA, Court NW (2004) Counting on mitogen-activated protein kinases-ERKs 3, 4, 5, 6, 7 and 8. Cell Signal 16:1345-1354

73. Dwivedi Y, Rizavi HS, Zhang H, Roberts RC, Conley RR, Pandey GN (2009) Aberrant extracellular signal-regulated kinase (ERK)1/2 signalling in suicide brain: role of ERK kinase 1 (MEK1). Int J Neuropsychopharmacol 12:1337-1354

74. Yuan P, Zhou R, Wang Y, Li X, Li J, Chen G, Guitart X, Manji HK (2010) Altered levels of extracellular signal-regulated kinase signaling proteins in postmortem frontal cortex of individuals with mood disorders and schizophrenia. J Affect Disord 124:164-169

75. Qi X, Lin W, Li J, Pan Y, Wang W (2006) The depressive-like behaviors are correlated with decreased phosphorylation of mitogen-activated protein kinases in rat brain following chronic forced swim stress. Behav Brain Res 175:233-240

76. Qi X, Lin W, Li J, Li H, Wang W, Wang D, Sun M (2008) Fluoxetine increases the activity of the ERK-CREB signal system and alleviates the depressive-like behavior in rats exposed to chronic forced swim stress. Neurobiol Dis 31:278-285 
77. Qi H, Mailliet F, Spedding M, Rocher C, Zhang X, Delagrange P, McEwen B, Jay TM, Svenningsson P (2009) Antidepressants reverse the attenuation of the neurotrophic MEK/MAPK cascade in frontal cortex by elevated platform stress; reversal of effects on LTP is associated with GluA1 phosphorylation. Neuropharmacology 56:37-46

78. Wang Z, Wang J, Li J, Wang X, Yao Y, Zhang X, Li C, Cheng Y, Ding G, Liu L, Ding Z (2011) MEK/ERKs signaling is essential for lithium-induced neurite outgrowth in N2a cells. Int J Dev Neurosci 29:415-422

79. Kim SH, Seo MS, Jeon WJ, Yu HS, Park HG, Jung GA, Lee HY, Kang UG, Kim YS (2008) Haloperidol regulates the phosphorylation level of the MEK-ERK-p90RSK signal pathway via protein phosphatase $2 \mathrm{~A}$ in the rat frontal cortex. Int J Neuropsychopharmacol 11:509-517

80. Shirayama Y, Chen AC, Nakagawa S, Russell DS, Duman RS (2002) Brain-derived neurotrophic factor produces antidepressant effects in behavioral models of depression. J Neurosci 22:3251-3261

81. Xing J, Ginty DD, Greenberg ME (1996) Coupling of the RASMAPK pathway to gene activation by RSK2, a growth factorregulated CREB kinase. Science 273:959-963

82. Drago A, Crisafulli C, Sidoti A, Serretti A (2011) The molecular interaction between the glutamatergic, noradrenergic, dopaminergic and serotoninergic systems informs a detailed genetic perspective on depressive phenotypes. Prog Neurobiol 94:418-460

83. Serretti A, Chiesa A, Calati R, Massat I, Linotte S, Kasper S, Lecrubier Y, Antonijevic I, Forray C, Snyder L, Bollen J, Zohar J, De Ronchi D, Souery D, Mendlewicz J (2011) A preliminary investigation of the influence of CREB1 gene on treatment resistance in major depression. J Affect Disord 128:56-63

84. Boer U, Cierny I, Krause D, Heinrich A, Lin H, Mayr G, Hiemke C, Knepel W (2008) Chronic lithium salt treatment reduces CRE/CREB-directed gene transcription and reverses its upregulation by chronic psychosocial stress in transgenic reporter gene mice. Neuropsychopharmacology 33:2407-2415

85. Dwivedi Y, Rao JS, Rizavi HS, Kotowski J, Conley RR, Roberts RC, Tamminga CA, Pandey GN (2003) Abnormal expression and functional characteristics of cyclic adenosine monophosphate response element binding protein in postmortem brain of suicide subjects. Arch Gen Psychiatry 60:273-282

86. Pandey GN, Dwivedi Y, Ren X, Rizavi HS, Roberts RC, Conley RR (2007) Cyclic amp response element-binding protein in post-mortem brain of teenage suicide victims: specific decrease in the prefrontal cortex but not the hippocampus. Int $\mathrm{J}$ Neuropsychopharmacol 10:621-629

87. Souery D, Zaninotto L, Calati R, Linotte S, Mendlewicz J, Sentissi O, Serretti A (2012) Depression across mood disorders: review and analysis in a clinical sample. Compr Psychiatry 53:24-38

88. Sheehan DV, Lecrubier Y, Sheehan KH, Amorim P, Janavs J, Weiller E, Hergueta T, Baker R, Dunbar GC (1998) The miniinternational neuropsychiatric interview (M.I.N.I.): the development and validation of a structured diagnostic psychiatric interview for DSM-IV and ICD-10. J Clin Psychiatry 59(Suppl 20):22-33 (quiz 34-57)

89. Hamilton M (1960) A rating scale for depression. J Neurol Neurosurg Psychiatry 23:56-62

90. Montgomery SA, Asberg M (1979) A new depression scale designed to be sensitive to change. Br J Psychiatry 134:382-389

91. Young RC, Biggs JT, Ziegler VE, Meyer DA (1978) A rating scale for mania: reliability, validity and sensitivity. Br J Psychiatry 133:429-435

92. Park S, Choi JW, Kyoung Yi K, Hong JP (2013) Suicide mortality and risk factors in the 12 months after discharge from psychiatric inpatient care in Korea: 1989-2006. Psychiatry Res 208:145-150
93. Wilkowska-Chmielewska J, Szelenberger W, Wojnar M (2013) Age-dependent symptomatology of depression in hospitalized patients and its implications for DSM-5. J Affect Disord 150:142-145

94. Oostervink F, Boomsma MM, Nolen WA, Board EA (2009) Bipolar disorder in the elderly; different effects of age and of age of onset. J Affect Disord 116:176-183

95. Angold A, Costello EJ, Erkanli A, Worthman CM (1999) Pubertal changes in hormone levels and depression in girls. Psychol Med 29:1043-1053

96. Angold A, Costello EJ (2006) Puberty and depression. Child Adolesc Psychiatr Clin N Am 15:919-937 (ix)

97. Clarke MC, Coughlan H, Harley M, Connor D, Power E, Lynch F, Fitzpatrick C, Cannon M (2014) The impact of adolescent cannabis use, mood disorder and lack of education on attempted suicide in young adulthood. World Psychiatry $13: 322-323$

98. Ostacher MJ, Lebeau RT, Perlis RH, Nierenberg AA, Lund HG, Moshier SJ, Sachs GS, Simon NM (2009) Cigarette smoking is associated with suicidality in bipolar disorder. Bipolar Disord 11:766-771

99. Seo HJ, Jung YE, Jeong S, Kim JB, Lee MS, Kim JM, Yim HW, Jun TY (2014) Personality traits associated with suicidal behaviors in patients with depression: the CRESCEND study. Compr Psychiatry 55(5): 1085-1092

100. Sareen J, Cox BJ, Afifi TO, de Graaf R, Asmundson GJ, ten Have M, Stein MB (2005) Anxiety disorders and risk for suicidal ideation and suicide attempts: a population-based longitudinal study of adults. Arch Gen Psychiatry 62:1249-1257

101. McElroy SL, Altshuler LL, Suppes T, Keck PE Jr, Frye MA, Denicoff KD, Nolen WA, Kupka RW, Leverich GS, Rochussen JR, Rush AJ, Post RM (2001) Axis i psychiatric comorbidity and its relationship to historical illness variables in 288 patients with bipolar disorder. Am J Psychiatry 158:420-426

102. Bauer MS, Altshuler L, Evans DR, Beresford T, Williford WO, Hauger R, Team VACS (2005) Prevalence and distinct correlates of anxiety, substance, and combined comorbidity in a multi-site public sector sample with bipolar disorder. J Affect Disord 85:301-315

103. Cassano GB, Pini S, Saettoni M, Dell'Osso L (1999) Multiple anxiety disorder comorbidity in patients with mood spectrum disorders with psychotic features. Am J Psychiatry 156:474-476

104. Chen YW, Dilsaver SC (1995) Comorbidity of panic disorder in bipolar illness: evidence from the epidemiologic catchment area survey. Am J Psychiatry 152:280-282

105. Chen YW, Dilsaver SC (1995) Comorbidity for obsessive-compulsive disorder in bipolar and unipolar disorders. Psychiatry Res 59:57-64

106. Rao KN, Kulkarni RR, Begum S (2013) Comorbidity of psychiatric and personality disorders in first suicide attempters. Indian J Psychol Med 35:75-79

107. Brent DA, Perper JA, Moritz G, Liotus L, Schweers J, Balach L, Roth C (1994) Familial risk factors for adolescent suicide: a case-control study. Acta Psychiatr Scand 89:52-58

108. Gould MS, Fisher P, Parides M, Flory M, Shaffer D (1996) Psychosocial risk factors of child and adolescent completed suicide. Arch Gen Psychiatry 53:1155-1162

109. Pawlak J, Dmitrzak-Weglarz M, Skibinska M, Szczepankiewicz A, Leszczynska-Rodziewicz A, Rajewska-Rager A, Zaremba D, Czerski P, Hauser J (2013) Suicide attempts and clinical risk factors in patients with bipolar and unipolar affective disorders. Gen Hosp Psychiatry 35:427-432

110. Tondo L, Lepri B, Baldessarini RJ (2007) Suicidal risks among 2826 sardinian major affective disorder patients. Acta Psychiatr Scand 116:419-428 
111. Pompili M, Innamorati M, Raja M, Falcone I, Ducci G, Angeletti G, Lester D, Girardi P, Tatarelli R, De Pisa E (2008) Suicide risk in depression and bipolar disorder: do impulsivenessaggressiveness and pharmacotherapy predict suicidal intent? Neuropsychiatr Dis Treat 4:247-255

112. Kim YK, Lee HP, Won SD, Park EY, Lee HY, Lee BH, Lee SW, Yoon D, Han C, Kim DJ, Choi SH (2007) Low plasma BDNF is associated with suicidal behavior in major depression. Prog Neuropsychopharmacol Biol Psychiatry 31:78-85

113. Keller S, Sarchiapone M, Zarrilli F, Videtic A, Ferraro A, Carli V, Sacchetti S, Lembo F, Angiolillo A, Jovanovic N, Pisanti F, Tomaiuolo R, Monticelli A, Balazic J, Roy A, Marusic A, Cocozza S, Fusco A, Bruni CB, Castaldo G, Chiariotti L (2010) Increased BDNF promoter methylation in the wernicke area of suicide subjects. Arch Gen Psychiatry 67:258-267

114. Hong CJ, Huo SJ, Yen FC, Tung CL, Pan GM, Tsai SJ (2003) Association study of a brain-derived neurotrophic-factor genetic polymorphism and mood disorders, age of onset and suicidal behavior. Neuropsychobiology 48:186-189
115. Pregelj P, Nedic G, Paska AV, Zupanc T, Nikolac M, Balazic J, Tomori M, Komel R, Seler DM, Pivac N (2011) The association between brain-derived neurotrophic factor polymorphism (BDNF Val66Met) and suicide. J Affect Disord 128:287-290

116. Dwivedi Y, Rizavi HS, Roberts RC, Conley RC, Tamminga CA, Pandey GN (2001) Reduced activation and expression of ERK1/2 map kinase in the post-mortem brain of depressed suicide subjects. J Neurochem 77:916-928

117. Einat H, Manji HK, Gould TD, Du J, Chen G (2003) Possible involvement of the ERK signaling cascade in bipolar disorder: behavioral leads from the study of mutant mice. Drug News Perspect 16:453-463

118. Schild AH, Pietschnig J, Tran US, Voracek M (2013) Genetic association studies between SNPs and suicidal behavior: a meta-analytical field synopsis. Prog Neuropsychopharmacol Biol Psychiatry 46:36-42 